\title{
The Development of Teachers' Pedagogical Competencies of Islamic Religious Education based on Learning Quality Management
}

\author{
Nurfuadi \\ Institut Agama Islam Negeri Purwokerto, Indonesia
}

Corresponding Author: Nurfuadi, $@$ nurfuadi.iainpwt@gmail.com

\begin{tabular}{|c|c|}
\hline & ABSTRACT \\
\hline $\begin{array}{c}\text { ARTICLE INFO } \\
\text { Article history: } \\
\text { Received } \\
\text { July 12, } 2020 \\
\text { Revised } \\
\text { August 10, } 2020 \\
\text { Accepted } \\
\text { December 08, } \\
2020\end{array}$ & $\begin{array}{l}\text { This article analyzed the teachers' role of Islamic Religious Education in } \\
\text { Madrasah, in managing learning to improve the good quality and } \\
\text { professional learning. This method used descriptive qualitative approach } \\
\text { by exploring the teachers in the management learning quality of three } \\
\text { schools, for instance Madrsah Aliyah (MA) Al-Ikhsan Beji Kedung } \\
\text { Banteng Banyumas, Madrasah Aliyah Negeri (MAN) } 1 \text { Banyumas, and } \\
\text { MAN } 2 \text { Banyumas. The competent and smart teachers would be able to } \\
\text { develop the students' learning, either in a professional or responsible } \\
\text { manner. Through pedagogical abilities, the teachers were able to } \\
\text { independently improve the development of their knowledge by } \\
\text { reviewing, internalizing, and realizing the output of learners competing in } \\
\text { the education world. The researcher found that professional teachers were } \\
\text { able to deliver the students to have a righteous attitude in both school and } \\
\text { outside of school. }\end{array}$ \\
\hline
\end{tabular}

Keywords: Teachers' Pedagogical Competencies, Learning Quality Management, Pedagogical Competence

How to cite $\quad$ Nurfuadi. (2020). The Development of Teachers' Pedagogical Competencies of Islamic Religious Education based on Learning Quality Management. Jurnal Iqra' : Kajian Ilmu Pendidikan, 5(2). 151-163.https://doi.org/10.25217/ji.v5i2.1014

Journal Homepage http://journal.iaimnumetrolampung.ac.id/index.php/ji/

This is an open access article under the CC BY SA license https://creativecommons.org/licenses/by-sa/4.0/

\section{INTRODUCTION}

Every teacher should have pedagogical competencies in learning process (Kosim, 2016). Therefore the importance of teacher competency mapping is to evaluate the factors that cause low teacher competence. In this context, Leonard (2016) discussed that there are at least four causes first, the inconsistency of scientific disciplines to the field of teaching. Where there are many teachers in schools who teach the subjects that are not in accordance with their basic knowledge skills. This is due to the problem of the lack of teachers in certain areas of study. Second, Secondly, the teacher qualifications are an unequal scholars. Consequently, the scientific standards of the teacher are inadequate to teach the field of study for which they are assigned. In fact, Not even a few teachers are scholars, but not in a set of educational scholars, and thus potentially become a problem in the pedagogic aspect. Third, the teacher's ongoing professional improvement (PKB) program. There are still many teachers who do not want to develop to add knowledge and competence in teaching. Teachers do not want to write, do not make scientific publications, or do innovative learning, most of them are just tend to teach Fourth, the recruitment of teachers is ineffective (Priansa, 2014; Yildiz \& Baltaci, 2017). Because there are still many prospective teachers who are 
recruited not through a professional mechanism, as required. Such conditions would certainly make teacher' competence getting lower

A research shows that the quality of education in Indonesia is ranked at 62 from 69 countries (Yunus, 2017). This becomes a concrete reflection on the quality and quantity of teachers in Indonesia. Then there must be serious steps to fix the quality of the teacher. Because in fact, not a few teachers today still run the teaching-learning process with a top-down pattern (Yunus, 2018). The teacher seems to be on top and students are below. Teachers act as subjects and students as learning objects. Teachers feel power to form their students. In the same way, other research revealed that teachers become teapots and students as an amusement, so that students only accept anything that the teacher has to do (Zuhaeriah, 2020). Students are not taught to explore their abilities. Students can only be told without being taught to know themselves and then survive. Teacher competence should be based on the ability to teach interesting, innovative, and creative lesson materials that can arouse students ' passion in learning (Ismawati, 2018; Suhadi, 2014). So, today, teachers are very much needed to transform the curriculum into learning units that can penetrate classrooms (Slattery; 2013). Classroom as the central room of teacher and student interactions should be enjoyable. Teachers don't need a curriculum that stifles creativity. The teacher should not be the dominant figure in the class. Teachers are not the ones who know everything; the teachers are not the key-based educator answers. But, student tutoring teachers know which areas of the lesson they are most favourite for. The big goal of curriculum change would be certainly futile when the teacher mindset does not change. Teachers are creators and don't need texts book on the curriculum. Teachers should not be comfortable with one-way learning, again the quality of education can only occur if the teacher teaches by heart, not just logic. Education would be more complicated in the future when the quality of our teachers is weak. Susanto \& Agustina, (2019) also found that the development of pedagogical competency models was essential in quality education. Because, the competency of teachers should be improved, that is important point of Indonesian education quality.

Furthermore, this research was different from the other previous studies above cause conducting in three madrasah, namely Madrasah Aliyah (MA) Al-Ikhsan Beji Kedungbanteng Banyumas, Madrasah Aliyah Negeri (MAN) 1 Banyumas, and Madrasah Aliyah Negeri 2 Banyumas. Beside in conducting pedagogical competencies, these three madrasah maximize the teachers' pedagogical competence of Islamic Religious education in the management of quality learning in Madrasah Aliyah Al-Ikhsan Beji Kedungbanteng Banyumas, Madrasah Aliyah Negeri 1 Banyumas, and Madrasah Aliyah Negeri 2 Banyumas. Furthermore, The implementation of teachers' pedagogical competence of Islamic education in quality management learning in three madrasah maximize the role of teachers' in pedagogic competence to improve the quality or the quality of learning. This current research was so essential to be conducted to maximize teachers' competent in the field of knowledge. Because the teacher has responsibility in the component of the educational institution and the most responsible in scoring students especially in the process of teaching and learning activities in the classroom and outside the classroom to realize the achievement of students and improve the quality of education. 


\section{METHOD}

The type of this research is field research. The data obtained from MA AlIkhsan Beji Kedung banteng Banyumas, MAN 1 Banyumas, and MAN 2 Banyumas sourced from interviews with teachers' of the Religious Education family. This study uses a descriptive qualitative approach by exploring teachers in the management of learning quality. The process of data analysis by organizing and sorting data into patterns, categories and basic units of description so thatcan becan be found themes and theories formulated based on data (Moleong, 2019). This study explored and analyzed data qualitatively to find the pedagogical competence of the Islamic Religious Education (PAI) family teacher in the management of the quality of learning in madrasas.

The step analysis is through observation or interview, which is verified and reduced. The first, categorization of data to formulate and support a hypothesis. Secondly, data is arranged in the form of units, the smallest part that can stand alone apart from the others but can be recognized and understood so that it can be used to form patterns. The third, each unit is collected into a unity in writing so as to form patterns of student motivation to learn. In that process simultaneous verification and triangulation of data occurs, both techniques (observation, in-depth interviews, documentation and questionnaires) as well as data sources (all research subjects) that run continuously in the entire span of data collection and analysis (Sugiyono, 2008; Glaser \& Strauss, 2017). Fourth, the systematic configuration of relations between hypothetical inference by dialoguing with various relevant theories so that a systematic and coherent pattern is built up as an answer to the formulation problem which means to build a theory. fifth, the theory is built and analyzed again to be standardized as a theory about the role of the PAI family teacher in organizing character education.

\section{RESULT AND DISCUSSION}

The Development of Teachers' Pedagogical Competencies of Islamic Religious Education based on Learning Quality Management in Madrasah Aliyah Al-Ikhsan Beji Banyumas

Basic concept of teacher's pedagogical competence of Islamic religious education in quality management of study of Madrasah Aliyah Al-Ikhsan Beji Kedungbanteng Banyumas in preparation of new academic year of activities related to the development of human resources through there is a workshop activity from the supervisors of the Ministry of Banyumas for one day at the MA Al-Ikhsan Beji Kedungbanteng starting from 08.30 to 14.00 with materials related to learning devices such as Prota and promissory note, although technically the implementation of the fact is carried out during the teaching learning activity is already running on Tuesday, September 10, 2019. In its implementation the first thing discussed is the discussion of prota and promises then RPP and continued by processing data or making prota, promissory note, RPP each participant computer with a duration of approximately 30 minutes. For prota and promes, the facilitator prota file is usually prepared by the facilitator so that the workshop participants only need to edit or adjust the subject of each teacher (Nada, 2019).

Supporting and inhibiting factors Pedagogical Competence of Islamic Religious Education teachers in the management of learning quality in Madrasah Aliyah AlIkhsan Beji Kedungbanteng Banyumas namely for supporting factors include cooperation between homeroom teachers and student guardians in establishing communication related to student development and some academic information, the 
existence of partnership between Madrasah Aliyah Al-Ikhsan Beji Kedungbanteng Banyumas and Al-Ikhsan Beji Kedungbanteng Islamic Boarding School and the existence of a synergy of mutual cooperation between teachers, parents and administrators of Al-Ikhsan Beji Kedungbanteng Islamic Boarding School in Banyumas, learning media such as projectors, laptops, blackboards, and collaborative cooperation between teachers, parents and administrators of Al-Ikhsan Beji Kedungbanteng Islamic Boarding School in Banyumas, learning media such as projectors, laptops, blackboards, blackboards. white board, media images, films, power points, speakers while the inhibiting factors include that the Islamic Cultural History material is too limited about the points being studied or lacks in detail, students' interest in learning in Islamic Cultural History subjects lacks motivation and teachers can not motivate learners because they need to understand the character of each student.

\section{The Development of Teachers' Pedagogical Competencies of Islamic Religious Education based on Quality Management in Madrasah Aliyah Negeri 1 Banyumas}

The concept and implementation of pedagogical competence of Islamic religious education of teachers, in the management of learning quality which is implemented in Madrasah Aliyah Banyumas 1 held a Workshop on learning quality based on Higher Order Thinking Skills (HOTS) using the KM 165 system and new revised on KM 183 in 2019, which is planned to be implemented starting from class $X$ by inviting speakers from the regional office of the Ministry of Religion.

The teacher gives pre-tests and post-tests, then the teacher gives direction so that students are demanded to be active, yo motivate students to be active in learning the teacher is always active first to share experiences and actively contribute to each other. Secondly, in teaching and learning activities using the discussion method when there are no students who dare to ask questions, the teacher as a facilitator allows students to ask into the context of other questions that are related to the material being studied. In motivating the next is the life values of an example related to the story behind the success of others it turns out there are twists and turns in achieving success (Budiman, 2014).

The factors in supporting the teacher's competence of Islamic religious education the management of learning quality in MAN 1 Banyumas include the background of students who are on average from Islamic boarding schools so that it is easy to understand the learning materials, complete infrastructure that support the activities of students in teaching and learning activities, the average human resources of teachers with Masters degrees, especially Islamic Religious Education teachers, and there is a madrasah policy which always take part in activities that support the quality of teachers through workshops, HOTS especially related to learning activity material, for example in making HOTS-based questions with a model of Core Competency activities, new Basic Competencies 183 and 184 (Lagorce, 2016; Toom, 2017). There is a significant madrasah policy, a reference book that is mutually supportive, mastery of the material by the teacher, and the deepening of the material from the teacher, the existence of supporting infrastructure, the existence of a good partnership between the homeroom teacher, student guardian to monitor each other students through Whatsapp group of each class as well as having a function in monitoring the development of students both in the madrasah / school environment and in outside the madrasah / school environment, The report of the activities of Duhur prayer in congregation by through monitoring by the mayor when following the Duhur prayer 
in congregation and the existence of a partnership between educational institutions/Madrasah Aliyah Negeri 1 Banyumas in the school/Madrasah environment with Pondok Pesantren Darussalam, Al-Jamil and Al-Amin (Santoso, 2019).

While the competency factor of teacher's pedagogical competence of Islamic religious education in the management of quality learning in Madrasah Aliyah Negeri 1 Banyumas is the policy of an activity that is often sudden from Kemenag such as renewal of data Education Management Information System (EMIS). Learners have a varied potential and learners come late into class, learners like to make rowdy in class and facilities are not yet adequate such as the laboratory of religious education only mosques and its not yet representative between the capacity of pilgrims with the number of pilgrims.

\section{The Development of Teachers' Pedagogical Competencies of Islamic Religious Education based on Learning Quality Management in Madrasah Aliyah Negeri 2 Banyumas.}

Pedagogical competence of Islamic religious education teachers in the management of learning quality that is applied in Madrasah Aliyah Negeri 2 Banyumas is IHT (In House Training) activities by inviting educational experts from universities around MAN 2 and usually the experts who have been invited are from the State Islamic Institute (IAIN) Purwokerto, in this case is Prof. H. Sunhaji, M.Ag. The material is examined in relation to how to design learning models (Miskiah; 2019), then in the even semester for the head of the Madrasah or often referred to as K3M (the Working Group of Madrasah) in the Banyumas which includes the districts of Banyumas, Purbalingga, Cilacap and Banjarnegara following the activities in the form of workshops. In the workshop K3M presenting the resource from the center of Jakarta Diklat Centre. While the material studied is related to HOTS-based learning (Hight Order Thinking Skill). On the design of the pedagogistic competence certainly does not ignore the core competence I (assessment of spiritual attitudes and 2 core competencies or social attitudes and should be assessed for the entire course of teaching is to be able to assess overall about the results of learners assessment of Islamic religious education includes core competencies $1=$ Spiritual, core competencies $2=$ social, core competencies 3= Knowledge dan core competencies $4=$ skill (Masran, 2018; Yasin, 2012). Core 1 competencies and Core 2 competencies in the form of introductory journals are the records of teachers' reports in general, e.g. Indonesian language teachers report to the teachers of Islamic Religious education, then there is a standard that is the intention of only monitoring students in the classroom, so the observation sheet related to spiritual attitude or core competence 1 is already listed in all subjects of the Islamic religious education, an example when the beginning of learning and the end of learning held activities Tadarus Al-Qur'an and Asmaul Husna, prayer Duhur congregation. On social observation assessments are usually enough in the picket room alone which includes discipline, honesty and craft of the learners, when there are findings for the students who violate the rules then reported to the teacher of Islamic religious education and PPKn teachers and after that newly reported to the class guardian. Every forty minutes at the beginning of learning is usually a method of Tahsin which is guided by JQH's supervisor (Jamiyatul Quro Wal hufadh). Technically the implementation is all students in each class to be able to follow the instructions of the coach through the active speaker media that is centralized from the source of the sound in the picket room which is then followed by all students simultaneously or 
together. Then in the forty minutes before the end of the lesson, the thirty-second Juz memorization was held, guided by JQH (Jamiyatul quro Wal hufadh) with the target to be able to memorize five to six letters a day depending on the short length of the letter. From these centralized activities, lessons can be taken positively, including when participants return to the madrasah together so when JQH (Jamiyatul quro Wal hufadh) Sadaqallahul 'Adim all students immediately pray and rush to the madrasa to their own house (Irfangi, 2019). Then the concept and implementation of the next pedagogic competence is that every morning before the lesson begins or precisely more there are fifteen picket teachers assigned to pick up learners admission to the Madrasah or school with technically the implementation for the male teacher to invite the male learners in front of the gate Madrasah while for female teachers to invite female learners in front of the gate Madrasah.

The supporting factors for the competency of pedagogic teachers of Islamic religious education in the management of quality learning in Madrasah Aliyah Negeri 2 Banyumas is the socialization of the parents to foster learners by means of monitoring in writing to the liaison book between the class and the parents and the program of study of the field, training of the Qur'an, practicum of Hajj and Janazah care.

While the inhibiting factors pedagogical competence of Islamic religious education teachers in the management of learning quality in Banyumas 2 Madrasah Aliyah include the background factors of students who have a diverse family environment so there needs to be a good partnership between the class guardian, parents of students and students with a pesrsuasif approach to students (Irfangi, 2019; Astuty, 2015). Pedagogic competence Teacher of Islamic religious education in quality management learning in the three Madrasah Aliyah in Banyumas District has a task and responsibility that is very important in improving the quality of learning in the institution/Madrasah. In Quality management learning many things should be evaluated for quality improvement of learning (Wakingah; 2018), as for the fact that in the field of the in-between through sharing activities that support the management of quality learning is to design learning models, then in the even semester for the head of Madrasah or often referred to as K3M (the Working Group of the Madrasah) in the Banyumas, which includes the districts of Banyumas, Purbalingga, Cilacap and Banjarnegara participated in the Workshop.. In the workshop, $\mathrm{K} 3 \mathrm{M}$ presented speakers from the center of Jakarta Diklat Centre. While the material studied is related to HOTSbased learning (Hight Order Thinking Skill). On the design of the pedagogistic competence certainly does not ignore the core competence I (assessment of spiritual attitudes and 2 core competencies or social attitudes and should be assessed for all subjects, namely to be able to assess overall about the results of learners assessment of Islamic religious education includes core competencies $1=$ Spiritual, core competencies 2 = social, core competencies $3=$ knowledge and core Competencies $4=$ skills.

Whereas the supporting and inhibiting factors include having cooperation between schools / madrasah with Al-Ikhsan Beji Kedungbanteng Islamic boarding schools, backgrounds of students who have a religious spirit that departing from a harmonious and ethical family background, the majority of female students make it easier to regulate / educate than female students and other supporting factors are adequate infrastructure, while the inhibiting factors include lack of synchronization in time for afternoon activities between Madrasah Aliyah and Pondok Pesantren because almost the average student lives in Pondok Pesantren, there is not the availability of canteen in the Madrasah Aliyah so that when resting many learners who are late in the classroom again to follow the because learners prefer to pick up in the cafeteria outside 
the Madrasah while relaxing that causes the teacher monitoring difficult and also cause many learners who are late following the next subject, another obstacle factor is the presence of a place of worship that is less representative of the mosque.

The teachers' Ppedagogical competence of Islamic religious education in the management of learning quality in Banyumas 1 State Madrasah, through the activity of Qur'an, Asmaul Husna before each in the first hour or before the lesson begins, the activities undertaken by each teacher picket to greet learners before the seven hours begins the lesson, the routine activities every Monday morning prayers together the entire Civitas Akademika after the flag ceremony on the field led by the prayer officers , the activity of memorization of short letters with targets for three years must be khatam by guided or guided by each teacher of the subjects, through the instructions in each class by the teacher BK, class Guardian, head of the Madrasah and through the activities of Duhur prayer in congregation in the mosque Madrasah Aliyah Negeri 1 Banyumas.

Supporting factors Pedagogical competence of Islamic Religious Education teachers in the management of learning quality in Madrasah Aliyah Negeri 1 Banyumas include a good partnership between the class Guardian, parents to monitor each student through the group Whatsapp in each class as well as has the function of monitoring students ' progress in both the Madrasah/school environment and outside the Madrasah/school environment, report of the activities of Duhur prayers in congregation by through monitoring by the mayor at the time of following the Duhur prayer in congregation and the existence of partnerships between educational institutions/Madrasah Aliyah Negeri 1 Banyumas in the school/Madrasah environment with Pondok Pesantren Darussalam, Al-Jamil and Al-Amin.

While inhibiting factors Pedagogical Competence of Islamic Religious Education teachers in the management of the quality of learning in Banyumas Aliyah 1 Madrasas is the lack of adequate infrastructure such as the laboratory of religious education (Masjid) that is not yet representative of the capacity of pilgrims with the number of existing worshipers. Meanwhile, According to Waka curriculum that has become a contributing factor among other mosques that have been representative, the Hall room for prayer activities in Congregation for the students are also representative, sound system is adequate/adequate and the teachers who have been quite a lot who are competent and as a factor of the termination is the existence of facilities/facility that is in the form of ablution that has not been adequate in the ratio between the number of students with facilities for ablution has not been fulfilled by the number of students 1,160 people while ablution place only has 5 places (Yusuf, 2019).

Pedagogical competence of Islamic religious education teachers in the management of learning quality that is applied in Madrasah Aliyah Negeri 2 Banyumas is IHT (In House Training) activities by inviting educational experts from universities around MAN 2 and usually the experts who have been invited are from the State Islamic Institute (IAIN) Purwokerto, in this case is Prof. H. Sunhaji, M.Ag. The material is examined in relation to how to design learning models, then in the even semester for the head of the Madrasah or often referred to as K3M (the Working Group of Madrasah) in the Banyumas which includes the districts of Banyumas, Purbalingga, Cilacap and Banjarnegara following the activities in the form of workshops. In the workshop K3M presenting the resource from the center of Jakarta Diklat Centre. While the material studied is related to HOTS-based learning (Hight Order Thinking Skill). On the design of the pedagogistic competence certainly does not ignore the core competence I (assessment of spiritual attitudes and 2 core competencies or social 
attitudes and should be assessed for the entire course of teaching is to be able to assess overall about the results of learners assessment of Islamic religious education includes core competencies $1=$ Spiritual, core competencies 2 = social, core competencies $3=$ Knowledge dan core competencies $4=$ skill.

Core 1 competencies and Core 2 competencies in the form of introductory journals are the records of teachers ' reports in general, e.g. Indonesian language teachers report to the teachers of Islamic Religious education, then there is a standard that is the intention of only monitoring students in the classroom, so the observation sheet related to spiritual attitude or core competence 1 is already listed in all subjects of the Islamic religious education, an example when the beginning of learning and the end of learning held activities Tadarus Al-Qur'an and Asmaul Husna, prayer Duhur congregation. On social observation assessments are usually enough in the picket room alone which includes discipline, honesty and craft of the learners, when there are findings for the students who violate the rules then reported to the teacher of Islamic religious education and PPKn teachers and after that newly reported to the class guardian. Every forty minutes at the beginning of learning is usually a method of Tahsin which is guided by JQH's supervisor (Jamiyatul Quro Wal hufadh). Technically the implementation is all students in each class to be able to follow the instructions of the coach through the active speaker media that is centralized from the source of the sound in the picket room which is then followed by all students simultaneously or together. Then in the forty minutes before the end of the lesson, the thirty-second Juz memorization was held, guided by JQH (Jamiyatul quro Wal hufadh) with the target to be able to memorize five to six letters a day depending on the short length of the letter. From these centralized activities, lessons can be taken positively, including when participants return to the madrasah together so when JQH (Jamiyatul quro Wal hufadh) Sadaqallahul 'Adim all students immediately pray and rush to the madrasa to their own house, Then the concept and implementation of the next pedagogic competence is that every morning before the lesson begins or precisely more there are fifteen picket teachers assigned to pick up learners admission to the Madrasah or school with technically the implementation for the male teacher to invite the male learners in front of the gate Madrasah while for female teachers to invite female learners in front of the gate Madrasah, Spiritual coaching for fifteen minutes before the teaching and learning activities in the hope of learners would have a strong spiritual mental ability and able to overcome all the problems in life and also through mentoring efforts to the learners of one of them by motivating learners to be more confident in learning and to be confident of his or her spiritual academic and mental ability to compete with each other to be honest and responsible, and in dressing students always pay attention to keep neatly dressed, beautiful and beautiful to be seen by others by keeping ahead of moral norms and rules applicable in Madrasah Aliyah Negeri 2 Banyumas and in each class usually every class Guardian always builds healthy communication with the parents to provide mutual information about the development of students both in the classroom and outside the classroom, especially related to the development of religious moral values, especially by seeing the development of social media technology that is very rapid development so that it gave an impact on a positive and negative side for students, and when looking at the negative impact of students is very alarming, especially when students open media services would be treated to a variety of menus or offerings of access to diverse information so students are required to be more selective in accessing information in accordance with positive needs such as looking for reference materials related to learning, therefore teachers or class guardian and parents 
must be able to partner well so that the development of learners can mutually monitor and share about each other's problems both in school or outside the school / madrasa, so that it would be more controlled about the development of students.

The supporting factors for the competency of pedagogic teachers of Islamic religious education in the management of quality learning in Madrasah Aliyah Negeri 2 Banyumas is a socialization to the parents to foster learners by means of monitoring in writing to the liaison books between the parents and the parents and the program of study of the field, training of the Quran, practice of Hajj and Janazah. Meanwhile, it is the obstacle of pedagogic competency teacher of Islamic religious education in the management of quality learning in Madrasah Aliyah Negeri 2 Banyumas including the supervision of learners handed over to the community that is sometimes unobjective when receiving or providing information to the institution or school/Madrasah Aliyah Negeri 2 Banyumas. According to Guru Aqidah Akhlak which is a contributing factor in pedagogic competence, among others, activities that support the education of attitude or affective such as a committee meeting that discusses related to the value of students ' affective, the event of Islamic Day Commemoration (PHBI) followed by all academic civitas including students should listen to the material submitted by the speaker, then students must be able to conclude the lecture material for the next result of his record brought home to be signed by parents of learners in the hopes that parents can learn about the results of his children in carrying out one of the duties in the Madrasah/school with the expectation of parents can be more attentive and wise in directing, to nurture their children continuously in the development of education. While the inhibitory factor in the pedagogic competence is a background factor of learners who have a diverse family environment so that the need for a good partnership between the class guardian, students parents and with a pesrsuasive approach to learners (Irani, 2019). On the supporting factor of pedagogic competence of teachers of Islamic religious education, with the holding of the program of the activities of the Qur'an and the implementation of curriculum for religious activities for students assessed by the teachers of Islamic religious education for the sake of filling the value of raport related to the charging of KI. I, while the termination factor is the presence of learners who are often late in school so as to cause the implementation of learning activities to be disturbed concentration and cause unrest or make rowdy in the classroom.

The result of this research is that the development of teachers' pedagogical competencies in Al-Ikhsan Beji by preparing a new school year by developing teachers through workshops from supervisors to ensure the teaching and learning activities by improving the annual program and semester programs. Meanwhile, in Madrasah Aliyah 1 Banyumas held a workshop on quality learning based on high level thinking skills using KM 165 system and revising KM 183 to improve the implementation of pedagogical competence in the management of learning quality. On the other, SMA Islam 2 Banyumas held an activity In House Training by inviting education experts from the surrounding universities in Purwokerto related to learning skills based on Hight think Order. Of the three research models above, the authors found that each madrasah has its own tendency and pattern depending on the financial and infrastructure capabilities. The authors found that the In-House training model activities were most linked to the Hight thinking skill Order to improve pedagogical competence. Learning would be successfully applied if each component in the Madrasah supports each other in the pedagogical competency development strategy of Islam. 
This research supported by the results of research by Balqis (2014) which states that the teachers' pedagogical competence in lesson planning at State Junior High School 3 Want Jaya, Aceh Besar District is carried out based on the curriculum and syllabus. In the lesson plan, it contains an analysis of learning material which includes competency standards, basic competencies, indicators and main material. Hakim (2017) also examined pedagogic competence which concluded that the pedagogic competence of Islamic Education teachers at State Junior High School 3 Tasikmalaya was good enough, where they were able to make lesson plans, create a comfortable learning atmosphere, create active learners in class; using a variety of teaching methods and media, understanding the diversity of student conditions, evaluating learning at once. Suharini's (2009) research shows that geography teacher's pedagogical competence is included in good criteria. Habibullah (2012) in his research concluded that the teacher's pedagogical competence in the aspect of learning knowledge ability was in the "lacking" category and the aspect of the ability to compile lesson plans was in the "sufficient" category. In line with the research that has been carried out, Anif (2019) concludes the results obtained by the mechanisms and procedures for the development of pedagogic competency development activities for biology teachers in the postcertification program in the Surakarta Residency. This is also in line with Gade (2020) which explains that overall, teachers of Islamic Religious Education who work at MAN in Aceh have been effective where teachers make PAI learning plans in the form of RPPs, have the skills to explain subject matter effectively, and have the skills to build interactions between Islamic Religious Education learning, as well as using various learning methods and media.

The results of this study can be used as material for consideration for teachers, students and educational institutions to determine the quality management of learning. The results of this study are closely related to teacher's competence. More than that, this research is also a reference where competent and intelligent teachers would be able to develop student learning, both professionally and responsibly. Through pedagogical abilities, teachers are able to independently improve the development of their knowledge by reviewing and internalizing, as well as realizing the outcomes of students in competing in the world of education. The author found that professional teachers are able to lead students to have the right attitude both at school and outside of school. This research would be useful in formulating education system policies in improving the quality of learning.

From these activities can be taken in positive wisdom among them when the participants come home all learners immediately pray and rushed to their homes, then the concept and implementation of the next pedagogic competence is that every morning before the lesson begins or precisely more there are fifteen picket teachers assigned to pick up learners admission to the Madrasah or school with technically the implementation for the male teacher to invite the male learners in front of the gate Madrasah while for female teachers to invite learners Women in front of the gates of spiritual coaching for fifteen minutes before the teaching and learning activities In the hope of learners will have a strong spiritual mental ability and able to overcome all the problems in life and also through mentoring efforts to the learners of one of them by motivating students to be more confident in learning and to be more confident in their academic and mental abilities to be able to compete with each other in an honest and responsible achievement. 


\section{CONCLUSION}

The development of teachers' pedagogical competencies of Islamic Religious education in the management of quality learning in MA Al-Ikhsan Beji Kedungbanteng Banyumas in the preparation of new school year activities related to the development of the teacher's human resources through workshop activities with materials related to learning devices such as Prota and promissory note, although technically the implementation of the fact is performed during the teaching learning activity is already running. In the first implementation discussed is about the discussion of Prota and promissory note then RPP and continued by processing data or making prota, promissory note, RPP on each participant's computer with a time duration of approximately 30 minutes. The development of teachers' pedagogical competencies of Islamic religious education in the quality management of learning that is applied in MAN 1 Banyumas, namely held a quality Workshop activities based on Higher Order Thinking Skill (HOTS) by using KM System 165 and the newly revised KM 183 year 2019 which is planned to be applied from class X. The first management of quality learning begins the teacher who gave pre-test and post-test. Teachers give instructions so that the students are required to be active. The development of teachers' pedagogical competencies in the management of quality learning who applied in MAN 2 Banyumas is generally at the beginning of the semester before the teaching activities held the existence of IHT (In House Training) activities by inviting education experts from universities around MAN 2 and usually experts who have been invited are from the Institute of Islamic Affairs (IAIN) Purwokerto, in this case it is Prof. H. Sunhaji, M.Ag. The material is examined in relation to how to design learning models, then in the even semester for the head of the Madrasah or often referred to as K3M (the Working Group of Madrasah) in the Banyumas which includes the districts of Banyumas, Purbalingga, Cilacap and Banjarnegara following the activities in the form of workshops. In the workshop K3M presenting the resource from the center of Jakarta Diklat Centre. While the material studied is related to HOTS-based learning (Hight Order Thinking Skill).

\section{ACKNOWLEDGEMENT}

This research was made as part of a series of large-funded research by Institut Agama Islam Negeri Purwokerto in the Decree of the Rector of IAIN Bone Number 782 May, Year 2019. This research was categorized the development of Study Program of Management Education.

\section{AUTHOR CONTRIBUTION STATEMENT}

All authors had fully taken participation in the research conduction and fully approved the final product of the manuscript writing.

\section{REFERENCES}

Anif, S., Sutama, \& Prayitno, H. J. (2019). Effectiveness of Pedagogical Competence: A Development Model Through Association of Biology Teachers' Forum. Jurnal Pendidikan IPA Indonesia JPII 8 (1) 22-31. https:// doi.org/10.15294/jpii.v8i1.17176

Astuty, E. (2015). "Implementation Analysis of Lecturer's Pedagogical Competence on Student's Academic Achievement." Journal of Management Research, 7 (2). 152. 
The Development of Teachers' Pedagogical Competencies of Islamic Religious Education based on Learning Quality Management

https:// doi.org/10.5296/jmr.v7i2.6834

Balqis, P., Usman, N., \& Ibrahim, S. (2014). Kompetensi Pedagogik Guru dalam Meningkatkan Motivasi Belajar Siswa pada SMPN 3 Ingin Jaya Kabupaten Aceh Besar. Jurnal Administrasi Pendidikan Volume 2, No. 1 pp. 25- 38. Google Scholar

Budiman, A., \& Jailani, J. (2014). Pengembangan instrumen asesmen higher order thinking skill (HOTS) pada mata pelajaran matematika SMP kelas VIII semester 1. Jurnal Riset Pendidikan Matematika, 1(2), 139-151. https:// doi.org/10.21831/jrpm.v1i2.2671

Gade, S. (2020). The New Curriculum in the Indonesian Educational System: Can Islamic Teachers Teach Better?. International Journal of Innovation, Creativity and Change Volume 13, Issue 9. Google Scholar

Glaser, Barney G, and Anselm L Strauss. Discovery of Grounded Theory: Strategies for Qualitative Research. Routledge, 2017. Google Scholar

Hakim, Lukman. “Development Strategy of Pedagogical Competence to Improve Professionalism of Islamic Education Teacher." Jurnal Pendidikan Islam 3, no. 2 (2018): 207. https:// doi.org/10.15575/jpi.v3i2.1406

Irfangi, M. (2019, 15 June). The Result Interview, Teacher, at Banyumas.

Ismawati, Nur. "Titik Tolak Pendidikan: Peningkatan Kualitas Guru." smktexmacosmg.sch.id, 2018. http://www.smktexmaco-smg.sch.id/artikel/view/titik-tolakpendidikan--peningkatan-kualitas-guru-6/.

Kosim, A. (2016). Kompetensi Pedagogik Guru dan Mutu Pembelajaran Pendidikan Agama Islam. Madaniyah, 6(2), 260-275. Google Scholar

Lagorce, X., Orchard, G., Galluppi, F., Shi, B. E., \& Benosman, R. B. (2016). Hots: a hierarchy of event-based time-surfaces for pattern recognition. IEEE transactions on pattern analysis and machine intelligence, 39(7), 1346-1359. https:// doi.org/10.1109/TPAMI.2016.2574707

Leonard, L. (2016). Kompetensi tenaga pendidik di Indonesia: Analisis dampak rendahnya kualitas SDM guru dan solusi perbaikannya. Formatif: Jurnal Ilmiah Pendidikan MIPA, 5(3). http:/ / dx.doi.org/10.30998/ formatif.v5i3.643

Masran, M., \& Esha, A. Z. (2018). Application of Higher Order Thinking Skills (Hots) in Teaching and Learning Process in Islamic Education. Advanced Science Letters, 24(7), 5326-5329. https:/ / doi.org/10.1166/asl.2018.11727

Moleong, Lexy J. Metodologi Penelitian Kualitatif (Edisi Revisi). Bandung: Rosda Karya, 2019. Google Scholar

Nada, Qotrun. (2019, 2 June). The Result Interview, Teacher, at Banyumas.

Priansa, Donni Juni. Kinerja Dan Profesionalisme Guru. Bandung: Alfabeta, 2014. Google Scholar

Santoso, A. (2019, 25 June). The Result Interview, Teacher, at Banyumas.

Slattery, P. (2013). Curriculum development in the postmodern era: Teaching and learning in an age of accountability. Routledge. Google Scholar

Susanto, R., \& Agustina, N. (2019). Development of pedagogical competency models for elementary school teachers: Pedagogical knowledge, reflective ability, emotional intelligence and instructional communication pattern. Universal Journal of Educational Research, 7(10), 2124-2032. Google Scholar

Sugiyono Metode Penelitian Kuantitatif, Kualitatif, Dan RED. Bandung: Alfabeta, 2008. Google Scholar

Suhadi, E., Mujahidin, E., Bahruddin, E., \& Tafsir, A. (2014). Pengembangan Motivasi 
The Development of Teachers' Pedagogical Competencies of Islamic Religious Education based on Learning Quality Management

dan Kompetensi Guru dalam Peningkatan Mutu Pembelajaran di Madrasah. Ta'dibuna: Jurnal Pendidikan Islam, 3(1), 42-60. http:/ / dx.doi.org/10.32832/ tadibuna.v3i1.570

Suharini, E. (2009). Studi Tentang Kompetensi Pedagogik dan Profesional Bagi Guru Geografi di SMA Negeri Kabupaten Pati. Jurnal Geografi Volume 6 No. 2 Juli. https:// doi.org/10.15294/jg.v6i2.99

Toom, A. (2017). Teachers' professional and pedagogical competencies: A complex divide between teacher work, teacher knowledge and teacher education. Handbook of research on teacher education, 2. https:/ / dx.doi.org/10.4135/9781529716627.n46

Yunus, Syarif. "Guru Atau Kurikulum: Titik Urgen Kualitas Pendidikan Indonesia ?" kumparan.com, 2018. https://kumparan.com/syarif-yunus/guru-ataukurikulum-titik-urgen-kualitas-pendidikan-indonesia.

- - . "Kenali 4 Penyebab Rendahnya Kompetensi Guru." detikNews, 2019. https://www.indonesiana.id/read/119880/empat-sebab-rendahnya-kompetensiguru.

Wakingah, W. (2018). Teknik Supervisi Individual: Peningkatan Kompetensi Pedagogik Guru Pendidikan Agama Islam dalam Mengembangkan RPP di Kota Yogyakarta. Jurnal Pendidikan Madrasah, 3(2), 345-357. https:// doi.org/10.14421/jpm.2018.32-07

Yasin, A. F. (2012). Pengembangan Kompetensi Pedagogik guru pendidikan Agama islam di madrasah (studi kasus di MIN Malang I). el-Qudwah. Google Scholar

Yildiz, A., \& Baltaci, S. (2017). Reflections from the Lesson Study for the Development of Techno-Pedagogical Competencies in Teaching Fractal Geometry. European Journal of Educational Research, 6(1), 41-50. Google Scholar

Yusuf. M. (2019, 09 September). The Result Interview, Waka Kurikulum MAN 1 Banyumas. At Banyumas

Miskiah, M., Suryono, Y., \& Sudrajat, A. (2019). Integration of information and comunication technology into Islamic Religious Education Teacher Training. Cakrawala Pendidikan, 38(1), 130-140. https:// doi.org/10.1080/01416200.2018.1484695

Zuhaeriah, Z., Ali, M., \& Yusra, Y. (2020). The Role of Islamic Education Teachers Competency in Improving the Quality of Education. International journal of $\begin{array}{lll}\text { contemporary islamic education, 2(1), 108-130. } & \text {. }\end{array}$ https:// doi.org/10.24239/ijcied.Vol2.Iss1.15

Copyright Holder :

(c) Nurfuadi N. (2020).

First Publication Right :

(C) Jurnal Iqra' : Kajian Ilmu Pendidikan

This article is under:

(ㅇ)(1) (2) 